\title{
Challenges of Track Access Charges Model Redesign
}

\author{
Branislav Bošković ${ }^{1}$, Mirjana Bugarinović ${ }^{1, *}\left(\mathbb{0}\right.$, Gordana Savić $^{2}(\mathbb{D})$ and Ratko Djuričić ${ }^{3}$ \\ 1 Faculty of Transport and Traffic Engineering, University of Belgrade, Vojvode Stepe 305, 11000 Belgrade, \\ Serbia; b.boskovic@sf.bg.ac.rs \\ 2 Faculty of Organizational Sciences, University of Belgrade, Jove Ilića 154, 11000 Belgrade, Serbia; \\ gordana.savic@fon.bg.ac.rs \\ 3 Faculty of Transport and Traffic Engineering, University of East Sarajevo, Vojvode Mišića 52, 74000 Doboj, \\ Republic of Srpska, Bosnia and Herzegovina; ratko.djuricic@sf.ues.rs.ba \\ * Correspondence: mirab@sf.bg.ac.rs; Tel.: +381-63-8074141
}

check for updates

Citation: Bošković, B.; Bugarinović, M.; Savić, G.; Djuričić, R. Challenges of Track Access Charges Model Redesign. Sustainability 2021, 13, 13512. https://doi.org/10.3390/ su132413512

Academic Editors: Davide Giglio and Alice Consilvio

Received: 6 November 2021

Accepted: 4 December 2021

Published: 7 December 2021

Publisher's Note: MDPI stays neutral with regard to jurisdictional claims in published maps and institutional affiliations.

Copyright: (c) 2021 by the authors. Licensee MDPI, Basel, Switzerland. This article is an open access article distributed under the terms and conditions of the Creative Commons Attribution (CC BY) license (https:/ / creativecommons.org/licenses/by/ $4.0 /)$.

\begin{abstract}
It has been exactly 20 years since the common grounds for the design of track access charges (TAC) were laid for the European railways by the publication of Directive 2001/14/EC. However, these grounds were defined broadly, thus resulting in significant divergence both in the models applied by countries and during the model redesign within one country over the course of time. The participants in the process of charge system redesign includes all stakeholders from a country's railway sector (infrastructure manager, train operating companies, the ministries responsible for transport, finance and economy, government, and regulatory bodies). Their opinions and requirements are often opposed, and they all need to be acknowledged simultaneously. This paper aims to solve the issue of ensuring continuity in the charge model redesign while achieving a balance between the requirements of all stakeholders. Moreover, it tackles the issue of producing a sustainable long-term TAC model by using survey methods and statistical analysis. The proposed approach was tested in practice during the access charge model redesign for the railways of Montenegro. The results show the importance of continual enhancement in TAC model development as one of the challenges and key precursors for the harmonization of all stakeholders' requirements.
\end{abstract}

Keywords: network management; track access charges; model; infrastructure; gap analysis; survey; sustainability

\section{Introduction}

Modernizing railways does not only imply the technical and technological advancements of railways but also their adjustment to market conditions, i.e., the restructuring that started 30 years ago in Europe when the European Commission published Directive $91 / 440 / \mathrm{EEC}$ on the development of the Community's railways. In fact, the processes of railway market restructuring and liberalization by way of introducing competition between train operators is a prerequisite for the valorization of the implemented technical and technological progress of railways.

Introducing and designing TAC system is a key element for railway market regulation and operation. Twenty years ago, the publication of Directive 2001/14/EC on the allocation of railway infrastructure capacity and the levying of charges laid common grounds for the design of charge systems and models within European railways. Additionally, in 2015, the EU published Regulation 909/2015/EU on the modalities for the calculation of costs that are directly incurred as a result of operating the train service. This Regulation defines the non-eligible costs for TAC modeling, but it does not specify what costs should be included in the calculation of direct costs on a network-wide basis in the TAC structure. However, due to the atomized European railway area and diverse national railway systems, these grounds were very broadly defined. This has resulted in significant heterogeneity of models and levels of charges for the minimum package of services involved in the use of railway infrastructure across the declared Single European Railway Area (SERA). Furthermore, the 
charge models have been significantly changed in some countries over the years, without continuity in their development. In other words, the models were unsustainable. Such an approach has disoriented the operators who had to introduce transport operation changes, aiming to reduce the expenses from access charges.

Access charges are key indicators of railway market liberalization and interoperability which have proven to be an essential economic pillar in the assessment and monitoring of railway sustainability [1]. Therefore, the access charge system redesign process should be comprehensive and include all stakeholders from a country's railway sector (infrastructure manager, train operating companies, the ministries responsible for transport, finance and economy, government, and regulatory bodies). This study suggests a methodology for obtaining the most important components and directions for adjusting the track access charge models to the needs of market actors and the responsible ministries and regulatory bodies. Their opinions and requirements are often opposed, and they all need to be acknowledged simultaneously during the charges model redesign. In addition, it is necessary to ensure the continuity and evolvability of charge model development so that the model redesign overcomes the inadequate elements and forms of the current model. Our aim is to contribute with an approach and method for ensuring continuity in the redesign of the charge model and the harmonization of all railway market actor requirements by using empirical research methods and tools to make a sustainable TAC model.

It is clear that railway market development and enhancement in infrastructure cost allocation will require a periodical revision to the access charge models. In this respect, this paper proposes an approach which enables the efficient redesign of the actual models and suggests the introduction of a new term: access charge model redesign. The approach is based on the active participation of all stakeholders in railway sector, which makes it particularly appealing from a regulatory point of view. In this study we introduce a procedure and a survey to conceptualize the redesign of TAC models and to define their main principles. A novel system-based approach in TAC design was tested on the case study of Montenegro railways.

The remainder of the paper is organized as follows. Section 2 describes the problem of charge model development in Europe, accompanied by brief review of literature. Section 3 outlines the methodological approach. Section 4 reports on participant group selection, data collection, and the results of the evaluation of attitudes for the example of Montenegrin Railways. Building on the results of the measurement of attitudes and opinions, the Conclusion points out the need to harmonize the requirements of all railway market participants regarding up-to-date access charges, and highlights the influential factors that determine the direction of an access charge redesign.

\section{Background}

The first track access charges were adopted in market conditions when there were one or possibly several operators. That was the moment of the opening-up of railway market. In the professional and scientific debate and literature, the issues of market development and the identification of obstacles or incentives for entry of new operators, access charges were often contemplated. Casullo [2] pointed out that competition in the market incentivizes train operators to put pressure on the infrastructure manager to reduce costs in order to reduce the access charges, which are the instruments for market regulation. In the European rail industry, to enable competition in the market, entrants should be granted access to a large set of complementary services beyond track access and adequate service charging [3]. For an efficient and effective market entry, non-discriminatory and adequate access charges are required $[4,5]$. This is quite expected, considering the size of challenges and the fact that facilitating competition between the train operating companies (hereinafter referred to as operators) on the network was the motive behind the restructuring. On the other hand, former incumbents tried to slow down this process by creating barriers against increased competition. They were successful in doing so since the regulatory bodies' lack of authority 
and capacity worked in their favor [6,7]. Increasing network competition is still largely present as a requirement when redesigning the charge system.

The period when there are several operators, but the competition is still weak, and the incumbents continue to dominate markets can be designated as the following or the second phase in TAC model development. Most European countries remain in this phase, since the characteristics of market frame and competition still prevail. This is particularly the case with small railways, which account for most railways in the Single European Railway Area. This period has brought about new issues in the development of charge models. Railway market actors and other stakeholders have pointed out various issues in the charge system. Different points of view of participants regarding the changes to the charges model result from their different interests. Consequently, they advocate for changes in a different manner. We should bear in mind that for some stakeholders, the TACs are on the cost side of operations, while for the others they are on the income side or they represent a mechanism for market regulation or a transport policy factor.

It seems that the teething period of charge modelling has already passed and that the requirements of railway market actors on the market (infrastructure manager and operators) and other stakeholders (governments, ministries, regulatory bodies and others) are becoming increasingly better articulated. These requirements result in governmental and ministerial decisions to implement a change in the track access charge model. In some countries, the changes in the model and its structure are rather frequent.

TAC modeling was preceded by studies on railway costing and pricing [8,9] and the transfer of infrastructure costs into track access charges [10]. All these studies highlight that there are now four types, or clusters, of track access charge structures (simple, simple plus, multiplicative and additive). A combination of these results and an analysis of access charge calculations in the 2020/2021 Network Statements for European countries are presented in the Figure 1. The data on changes in the type of charges since 2013, along with the current charges (2021) in European countries, are given in parallel. The direction of changes in the types of charges by countries in the observed period are indicated by red arrows.

In the observed period of last 8 years, beginning in 2013 when the implementation of Directive 2012/34/EU for access charges began, it can be noticed that many countries (18) kept the same formula structure, while ten countries had changes in structure (Bulgaria, Lithuania, Norway, Latvia, Sweden, Hungary, Switzerland, Romania, Germany and Slovenia). In 2013, the simple and additive formula structures had the largest representation, whereas today (2021) the additive structure prevails, with 13 countries out of the observed 28. We note that there are two exceptions. These are Germany and Slovenia. It can be said that they are going in the opposite direction of changing the type of charges.

Changes in the types of charges represent a significant shift in the structure and elements used to calculate the level of charges. For the operator, this means a change in the valid value system, which consequently requires making efforts to adjust the organization of transport by aiming to reduce the expenses related to access charges. Even though the observed period is long, we can conclude that the charge models have changed significantly, during this time, within the European railways. For example, Germany has changed the charge model five times [11,12] but only changed the type of charges in 2020, France changed its model twice, but the charge type has always been additive [13-15]. When it comes to small railways, Croatia changed its elements and ponders five times with [16] and Montenegro for four times [17], but the types of charges stayed the same in both countries.

Finally, the increased presence of additive-type charges in 2021 indicates that, over the course of time, the charge structures have become more complex and now contain more elements than before. 


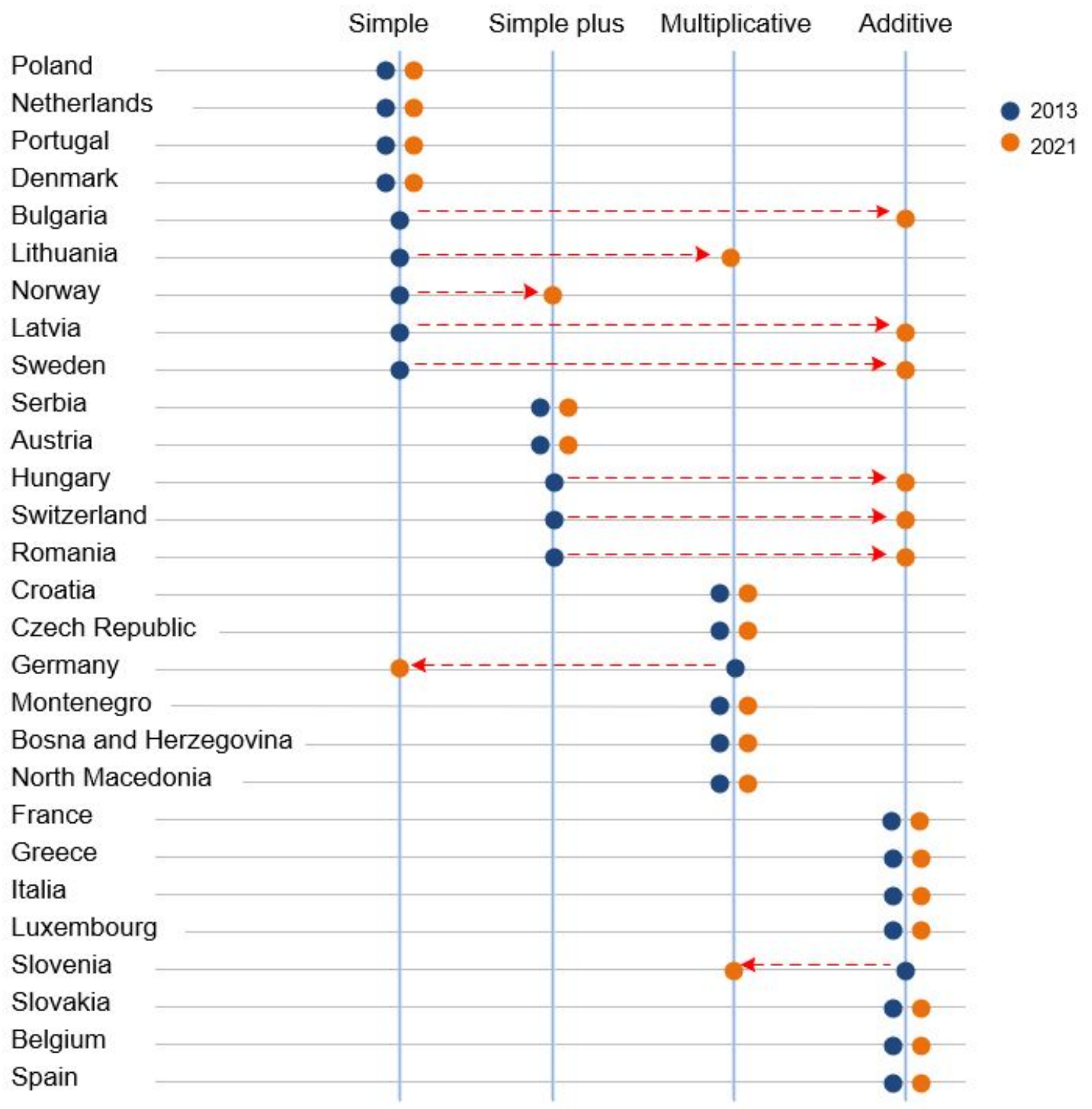

Figure 1. Type of charge changes within European railways according to status in 2013 and 2021 (Source: Author).

A small number of studies have identified a range of problems treating the structure or elements of some track access charges. Nash [18] reviewed the TACs in 23 countries and found a wide variety of both structures and levels of charges. It appears there is a range of explanations for this, including differences in the nature and mix of rail traffic, differences in the willingness and ability of governments to provide subsidies, and continued lack of consensus on the measurement of the marginal cost of infrastructure use. According to the Ciuffini and Rotoli $[19,20]$, the diversity of approaches to a TAC modeling poses problems. Providing system-based approach to access charges in unbundling railways, Bugarinovic [21] indicates that, with charges defined by cost, traffic and network modalities, it is possible to track cost and cost management by services. All these examine TAC modeling from different perspectives, and none of them address challenges as to how to further develop or revisit the adequacy of an access charge model.

The period since the market liberalization can be also characterized as a period of large changes in the systems of charges in particular countries. In addition to the model redesign, the operator requirements are also directed towards the stabilization of the access charge principle. For this reason, subsequent challenges to the charge model redesign and increasing stakeholders involvement can be expected. The basic idea of this paper is based on the hypothesis that, when designing the charge model, it is essential to set up continuity 
in order to avoid the disruption between the current and the new models and to set up an evolvable, sustainable and stable regime of charges. Sustainability and continuity can be set up if the process of designing the charge model begins with a gap analysis based on the opinions and experiences of railway market actors and other stakeholders to enumerate the gaps and shortcomings in the current charge model, and to determine whether principles upon which the charges are to be redesigned are included.

The objective of this paper is to define a methodology for diagnosing gaps and shortcomings in an extant charge system. The survey has been defined and the relevant statistical data processing has been performed. The fact that speaks in favor of this approach is that the survey method is a generally accepted standard technique in transport scenario studies [22], where survey results are used by public authorities and institutions as scientific instruments in the adoption of particular measures. The survey is a process of empirical research enabling the systematic solicitation of anonymous informed judgements on a particular topic, where the feedback of the group's opinion is provided [23]. We implemented this research method in the charge model redesign for the railways in Montenegro.

The proposed methodology enables infrastructure manager to decide how to approach the redesign of a system of charges without directly determining the functions of supply and demand that require more detailed market data over a longer period of time, and by combining several aspects (legislative, cost-related, market-related) and opinions of several actors.

\section{Methodology}

This section explains the methodology used in this research. The concept of redesigning the current TAC has required the identification of their gaps and shortcomings as well as the principles upon which the existing charge will be changed.

A six-step methodology was proposed: (1) identification of the gaps and shortcomings of the current TAC model considering the changes and requirements in the EU legislation framework; (2) definition of form and content of a survey for to diagnose the benefits and shortcomings of the current TAC model and the requirements of stakeholders regarding the model and the level of charges; (3) determining a representative group of participants from railway market actors and other stakeholders; (4) collecting responses; (5) relevant statistic survey analyses; and (6) formulation of principles for the TAC model redesign based on the survey results. The complete procedure presented in Figure 2 needs to be repeated periodically in order to develop a sustainable TAC model.

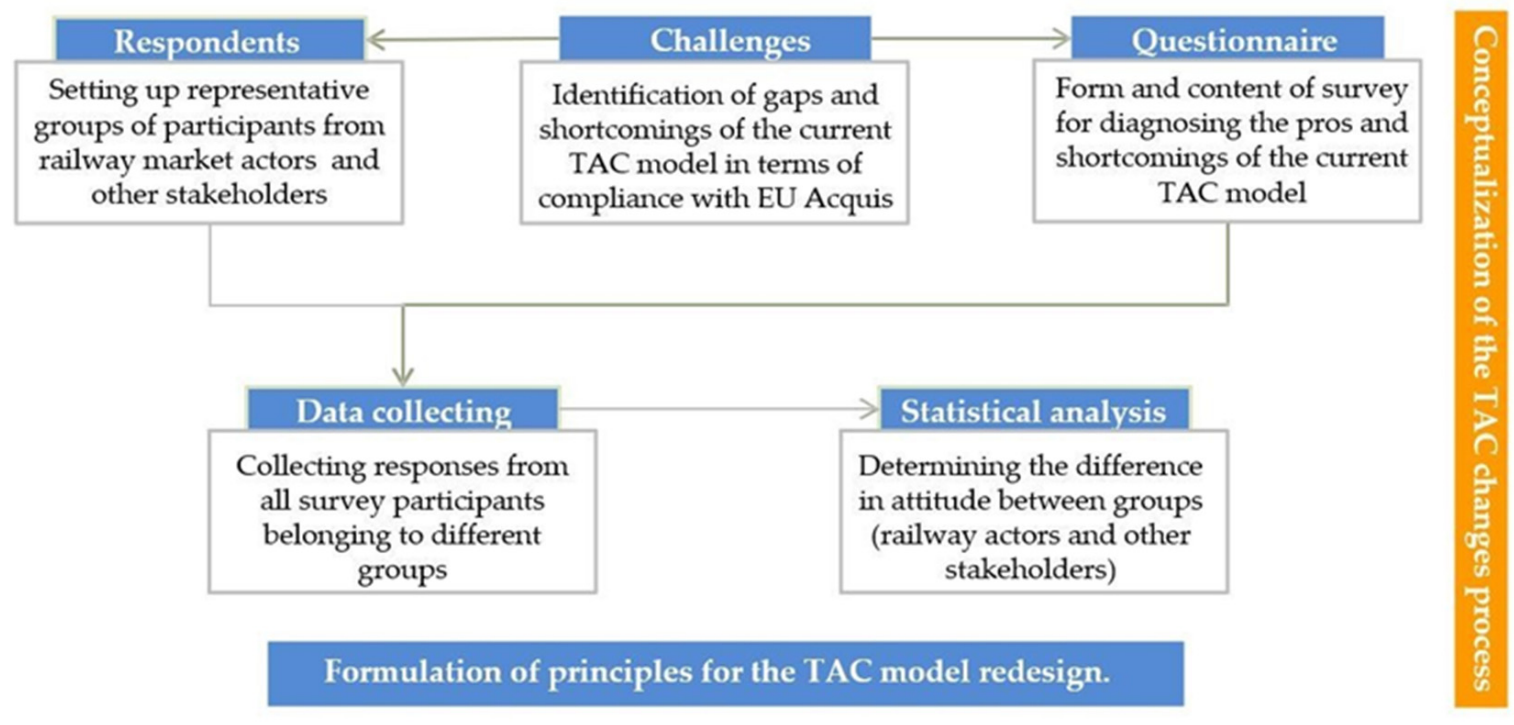

Figure 2. Methodological procedure. 
Step 1: analysis of the existing TAC model and its compliance with changes in legal frameworks, especially in the field of cost management and allocation for infrastructure manager, determination of direct costs, calculation of access charges for network-users, cost requirements for market segmentation, and other issues.

Step 2: the relevance of the challenges was measured by undertaking a survey among railway market actors and other stakeholders. The challenges were outlined in the form of statements, such as: (1) shortcomings and benefits of the existing structure of charges, and (2) interests and requirements of all stakeholders regarding the model and level of charges.

A questionnaire survey was prepared comprising two sections. The first part sought to define the shortcomings of the existing TAC method and structure, while the second sought to explore the requirements regarding the direction of charge development suggested by all stakeholders. The closed questions format was used (copies of which are available from the authors). A detailed questionnaire is provided in Table A1 in the Appendix A.

The surveys assessed to what extent the respondents agreed with several statements regarding a certain topic using a Likert scale. The Likert scale uses the fixed choice response formats, and it is designed to measure attitudes and opinions on the ordinal scale [24]. The ordinal scale used in this paper was a 3-point scale (agree, neutral and disagree) and it enabled respondents to express to what extent they agree or disagreed with each statement. As such, Likert scales have found application in psychology, the social sciences, statistics, business and marketing [25].

In this paper the Likert scale was used to evaluate a set of statements that were oriented on two issues, identification of the shortcomings of the current TACs, and the interest in and requirements for the future TACs. The statements were not presented as individual statements where each statement bears its own information. The survey consisted of 12 closed questions, i.e., offered statements.

Step 3: a respondent sample was drawn from the list of top managers and heads of departments from railway market actors and other stakeholders. The railway market actors could be divided into three groups because they consider access charges from different perspectives. In other words, they have different requirements and interests. Increased charges represent expenses for operators and revenue for infrastructure manager. The third group consisted of participants from other stakeholders i.e., the Ministry of Transport, Ministry of Finance and railway authority in Montenegro.

Step 4-5: data were collected by conducting the survey with all selected participants from three groups. Questionnaire results were tabulated. The shortcomings of the current TACs and requirements were ranked, and the levels of the significance of the responses were tested using statistical analyses. We used the Kruskal-Wallis [26,27] rank-based non-parametric test to determine whether there were statistically significant differences in attitudes to current TAC models among the selected groups. Therefore, one test was performed for each survey question.

Step 6: the implemented survey resulted in a proposal of principles (and directions) upon which changes to the charges model and structure were to be based. In other words, the survey result represents an answer to the question of how and what should be changed in the current TAC.

\section{Evaluation of Components for TAC Changes: The Case of Montenegro}

We implemented proposed procedure in the process of TAC changes in Montenegro in order to determine which TAC model would be most acceptable to the stakeholders and follow the EU legislation.

\subsection{Participant Group Selection and Data Collection}

The railway market actors list consisted of (1) infrastructure manager (ŽICG, JSC) and operators: (2) freight operator (Montecargo, JSC), (3) passenger operator (ŽPCG, JSC), and (4) private freight operator ("16 February" representatives). They could be divided into two groups because they considered access charges from different perspectives. In other 
words, they had different requirements and interests. Increased charges represent expenses for operators and revenue for infrastructure manager. The third group, a sample of the other stakeholders, consisted of representatives from the (5) Ministry of Transport (Railway Directorate), (6) Ministry of Finance, and (7) railway authority in Montenegro. The selected respondents from this group were involved in monitoring the railway market and charges, i.e., in making decisions regarding TAC development. The survey was implemented in direct contact with the representatives at the arranged meetings in September 2020.

Twenty-four representatives were interviewed and indicated willingness for intensive cooperation (Table 1). Having in mind the topic, the survey population is small and consists of state administration members and top managers in national railway companies.

Table 1. The data on respondents/number of respondents per group.

\begin{tabular}{|c|c|c|c|c|c|}
\hline \multirow[b]{3}{*}{ Respondent Group } & \multicolumn{5}{|c|}{ Number of Respondents Per Group } \\
\hline & \multirow[b]{2}{*}{$\begin{array}{c}\text { General/ } \\
\text { Deputy } \\
\text { Director }\end{array}$} & \multicolumn{4}{|c|}{ Director or Head of Department for } \\
\hline & & $\begin{array}{c}\text { Traffic; } \\
\text { Signaling; } \\
\text { Civil Eng. }\end{array}$ & Economic & Budget & $\begin{array}{c}\text { Market } \\
\text { Regulation }\end{array}$ \\
\hline \multicolumn{6}{|l|}{ Railway market actors } \\
\hline (1) Infrastructure manager & 3 & 9 & 1 & & \\
\hline (2) Freight operator (incumbent) & & 1 & 1 & & \\
\hline $\begin{array}{l}\text { (3) Passenger operator } \\
\text { (incumbent) }\end{array}$ & & 1 & 2 & & \\
\hline (4) Private freight operator & 1 & & 1 & & \\
\hline \multicolumn{6}{|l|}{ Other Stakeholders } \\
\hline $\begin{array}{l}\text { (5) Competent Ministry of } \\
\text { Transport }\end{array}$ & 2 & & & & \\
\hline (6) Ministry of Finance & & & & 1 & \\
\hline (7) Railway Authority & & & & & 1 \\
\hline Total & 6 & 11 & 5 & 1 & 1 \\
\hline
\end{tabular}

If we consider the countries with small railways, then the relevant survey population would include between 20 and 50 persons [28]. Hence, in this case, sample representativity was not achieved by sample size but by including the representatives of all actors and stakeholders in the railway market. Furthermore, we believe that the sample was balanced by including the relevant number of representatives from railway market actors and other stakeholders.

In addition, the involvement of representatives from the ministries and railway authority provided broader insight into railway market requirements for TAC decision-making regarding access charge levels. These questions were posed in both sections of the survey but they were mostly focused in the section dealing with cost coverage and expectations from TAC in general.

Data were collected by exposing the questionnaire to all selected participants in survey.

\subsection{Results and Discussion}

Before recommending a TAC redesign, we sought to understand the gaps and shortcomings of the current methodology and TAC structure. Out of the factors presented in a closed questionnaire, the questions of which costs are to be included in the unit price and the clarity of relations were considered to be the most important factors justifying the formula redesign (Table 2). This means that the current TAC formula does not realistically reflect the costs incurred as a result of operating the train service, i.e., the use of infrastructure, and that the relationships between the elements in the current TAC formula are obsolete. Consequently, the structure of the charges is not sending clear messages to the operators as to which direction and upon which segments of operation they should act in 
order to reduce expenses from access charges to become more competitive in the transport market.

Table 2. Shortcomings of the current TAC structure (formula).

\begin{tabular}{lll}
\hline Question Number & Number of Responses & \multicolumn{1}{c}{$\begin{array}{c}\text { Question Description } \\
\text { Q8 }\end{array}$} \\
\hline Q1 & 16 (agree) & $\begin{array}{l}\text { Relations between the elements in the current } \\
\text { TAC formula are obsolete and do not reflect } \\
\text { the unit costs by place of origin and cause. }\end{array}$ \\
\hline Q7 & 15 (agree) & $\begin{array}{l}\text { Cost covering based on which the unit price is } \\
\text { defined is non-transparent and unclear. }\end{array}$ \\
\hline Q2 & 13 (agree) & $\begin{array}{l}\text { There should be a clear differentiation between } \\
\text { the charging of infrastructure capacities and } \\
\text { wear and tear in the formula for calculation of } \\
\text { charges. }\end{array}$ \\
\hline Q10 & 13 (disagree) & $\begin{array}{l}\text { The costs included in the current model do not } \\
\text { satisfy the requirements of Directive } 909 / 2015 .\end{array}$ \\
\hline Q9 & $\begin{array}{l}\text { Train weight classes and the corresponding } \\
\text { coefficient value are adequate (based on } \\
\text { objective research). }\end{array}$ \\
\hline
\end{tabular}

Table 2 reveals other motivations including dissatisfaction with the definition of unit access charges and the possibility of offering clients/train operators clear differentiation of infrastructure capacity and wear and tear charging. It should be noted that dissatisfaction with unit cost was at the heart of all the shortcomings chosen. Everyone thinks that the infrastructure manager should clearly indicate whether and how much it wants to charge for capacity, wear and tear of infrastructure, or both.

Finally, analyzing this set of questions (Table 2) we concluded that the respondents from all three groups were of the opinion that the infrastructure manager should manage its costs better way, and that this should be reflected in the structure of charges.

In most cases, interests and requirements were sublimated in questionnaires number 6 and 3 (Table 3). Most respondents said that the level of charges should clearly reflect the cost of market segments and significantly affect operator competitiveness.

Most of the respondents $(66.7 \%)$ agreed that the level of charges for passenger and freight trains was unfair and irrational. This was also the opinion of the passenger operator representatives, who were fully aware that the existing disproportion in charges as unsustainable (the average charges depending on train weights per train $\mathrm{km}$ for freight trains are 1.9 to 2.8 times higher than the charges for passenger trains [29]), although the financial status of the passenger operator in Montenegro was very poor due to large debts and unsettled financial obligations towards suppliers and the State.

The question of whether the level of charges according to the current model significantly affects the competitiveness of railway operators on the transport market was primarily aimed at freight operators. All the representatives from the freight operators responded with "agree," as did a significant number of representatives (63\%) from the state administration and infrastructure manager. This shows us that the awareness about the high level of charges in Montenegro is present at all railway sector levels. The representatives from the passenger operator responded with "disagree". This was expected since their competitiveness in small countries with low traffic flows such as Montenegro depends primarily on state support through compensation within the PSO system. 
Table 3. Set of questions and responses corresponding to the interests and requirements of railway market actors and other stakeholders.

\begin{tabular}{|c|c|c|}
\hline Question Number & Number of Responses & Question Description \\
\hline Q6 & 16 (agree) & $\begin{array}{l}\text { The level of charges for passenger and freight } \\
\text { trains is unfair and the ratio is non-rational. }\end{array}$ \\
\hline Q3 & 15 (agree) & $\begin{array}{l}\text { The level of charges is such that it significantly } \\
\text { affects the operator's competitiveness on the } \\
\text { transport market }\end{array}$ \\
\hline Q11 & 14 (agree) & Charging for path reservation is a problem \\
\hline Q5 & 13 (disagree) & $\begin{array}{l}\text { TAC methodology is fully complied with the } \\
\text { EU legislation requirements }\end{array}$ \\
\hline Q12 & 10 (disagree) & $\begin{array}{l}\text { The system of charges for train delays is } \\
\text { well-defined and acceptable. }\end{array}$ \\
\hline Q4 & 5 (agree) & $\begin{array}{l}\text { The budget and budgetary restrictions for the } \\
\text { infrastructure manager are } \\
\text { unknown/uncertain during the TAC model } \\
\text { development and thus negatively impact the } \\
\text { TAC redesign and level of charges }\end{array}$ \\
\hline
\end{tabular}

If we look at the frequencies of responses by groups (Figure 3), group 2, which consists of infrastructure manager representatives, has the highest number of neutral responses. This attitude of the infrastructure manager towards TAC can be characterized as "noninterested" and justified with the small share of charges in its total revenues ( $8 \%$ in 2020). Furthermore, the positions of infrastructure manager, which is monopolistic, and a small number of operators on the market additionally motivated "neutral" responses. The basic characteristic of the responses from group 1 is that they fully agreed with the statements in questions No. 1, 2 and 8. This group of respondents emphasized that the redesigned charges should be fully in accordance with the EU legislation requirements and that the underlying cost principle should be transparent. This finding was additionally confirmed by the previous experiences with numerous complaints submitted by the operators to the regulatory body of Montenegro, thereby showing that these are the "pressing" issues that need to be resolved.

Most of the respondents from all three groups thought that the classes of train weights and the corresponding coefficient levels were not adequate, i.e., that they are not based on objective research (Question 10). Some comments suggested that a different categorization of weight was required, and some suggested that it was necessary to consider a particular train's weight when determining the level of charges. A train consisting of empty wagons was sometimes heavier than a loaded train, thus causing higher track wear and tear costs, but according to the formula the access charge for such a train is lower. Such a disproportion results from the fact that the wear and tear coefficients are defined separately for trains with empty wagons and for locomotive trains, and not in correlation with the train weight.

In order to test if the response pattern could have occurred by chance, a Kruskal-Wallis $H$ test was employed [26,27]. With 2 degrees of freedom and a confidence level of 0.05 , the critical value $\chi^{2}(2)=5.991$ (an orange color line in Figure 4). The null hypothesis that there was no difference in the results between groups is rejected when the response rate exceeds this value. The results are presented in Figure 4. 


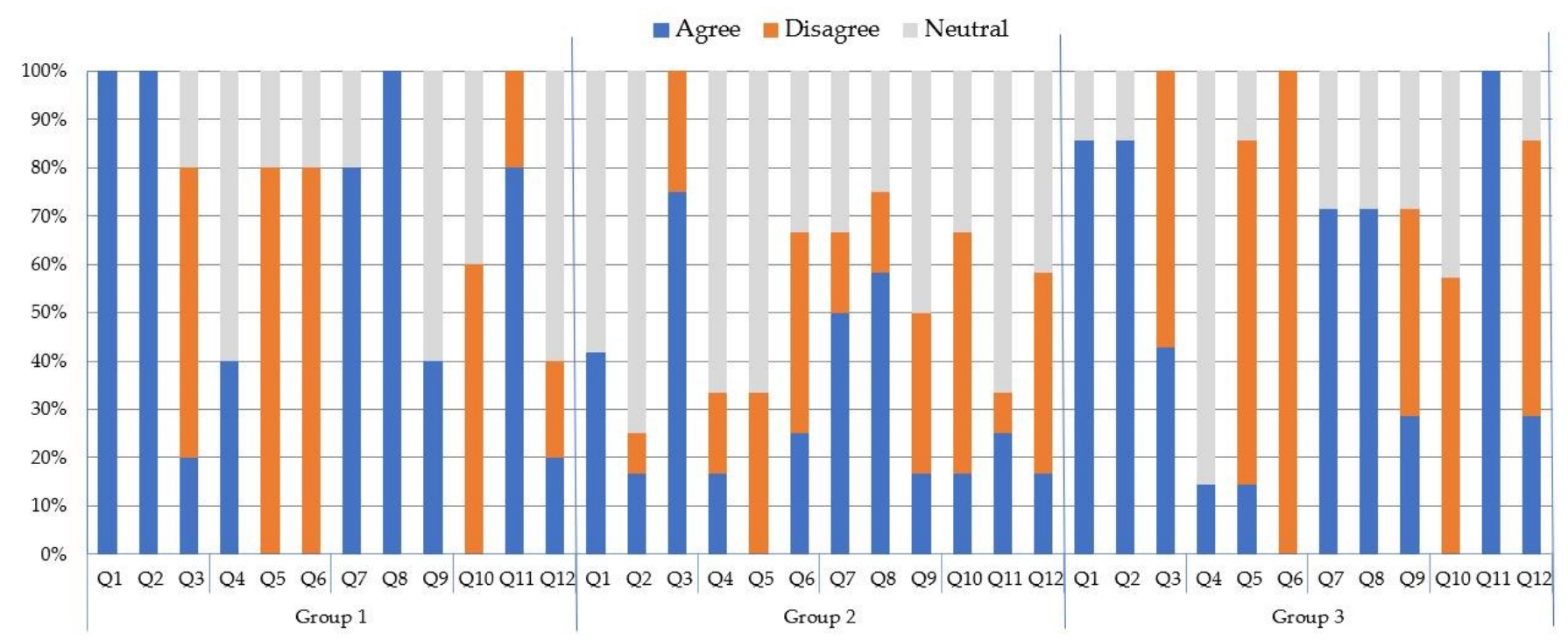

Figure 3. Frequency of responses per question for each respondent group.

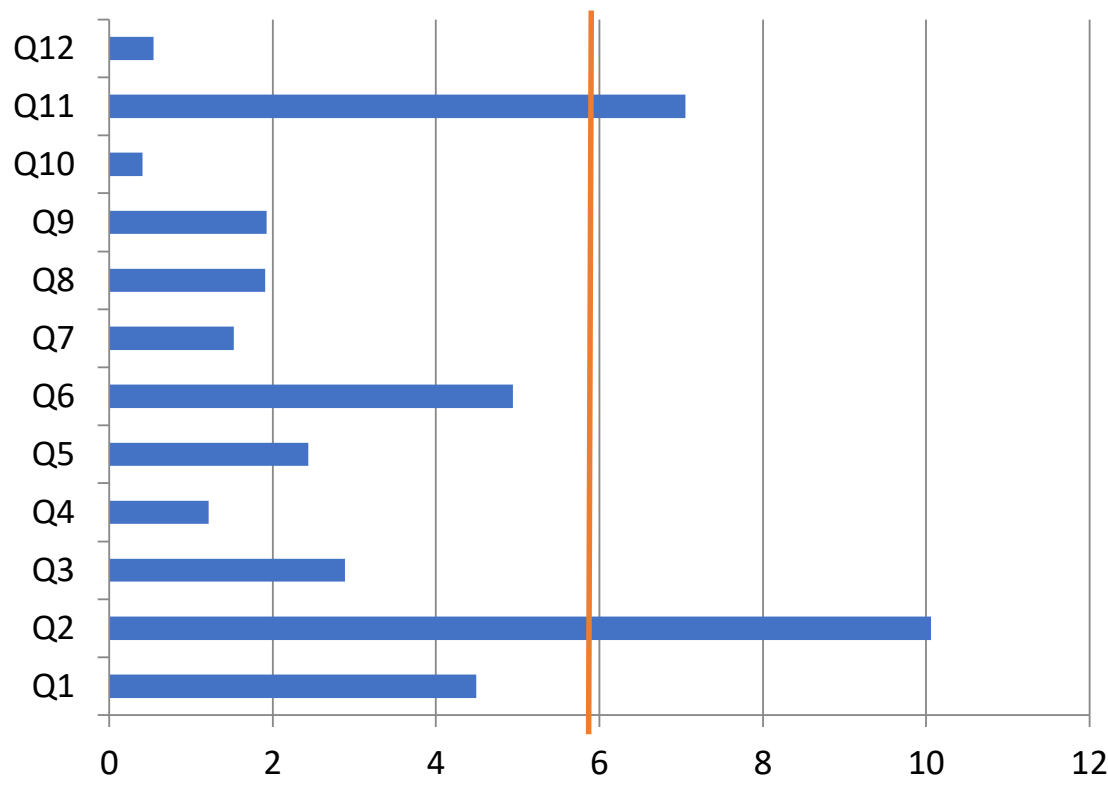

Figure 4. Results of the chi square $\left(\chi^{2}\right)$ test.

Two questions produced statistically significant disagreement. Firstly, most of the respondents agreed that the costs included in the model do not satisfy the requirements of Regulation 909/2015/EU (question 2, with $\chi^{2}(2)$ of 10.058). The operators and the state administration considered this question very important due to different reasons. The ministries for transport and finance and the regulatory body, saw this as a question of the harmonization of rules for the railway market of Montenegro with EU legislation, as part of the process of EU integration. The operators saw this as a chance for reduced charges since the Regulation 909/2015/EU on the modalities for the calculation of the costs directly incurred as a result of operating the train service has restrictive cost covering, as compared to the possible cost covering applied in the extant model of charges in Montenegro. It is interesting that the representatives from the infrastructure manager mostly opted for the "neutral" responses. 
Secondly, charging for path reservations is a problem (question 11 with $\chi^{2}(2)$ of 7.051). Operators (group 3) perceived charging for path reservations as a problem, since in conditions when the capacity of the railway network in Montenegro is poorly utilized, they thought that no charges for path reservation should be introduced, whereas the respondents from the infrastructure manager and state administration were predominantly "neutral".

Based on the analysis of the results of survey conducted with the stakeholders and railway market actors in Montenegro, the following directions for TAC redesign were determined (Table 4).

Table 4. TAC modeling principle.

\begin{tabular}{ll}
\hline \multicolumn{1}{c}{ Area } & \\
\hline Legislative & To fully comply with all the EU legislative requirements; \\
\hline \multirow{3}{*}{$\begin{array}{l}\text { Costs } \\
\text { (coverage } \\
\text { and cost } \\
\text { managing) }\end{array}$} & $\begin{array}{l}\text { To be based on the direct costs incurred as a result of operating the train service; } \\
\text { To be tailor-made with the implemented degree of cost allocation in the actual } \\
\text { bookkeeping of ZICG JSC; }\end{array}$ \\
\cline { 2 - 3 } & $\begin{array}{l}\text { To be designed and structured in order to indicate to the infrastructure manager } \\
\text { (ZICG JSC) the directions and areas for improvement in cost management and } \\
\text { rationalization; }\end{array}$ \\
\hline \multirow{3}{*}{ Competition } & $\begin{array}{l}\text { To enable the infrastructure manager to increase the volume of revenues from } \\
\text { charges without jeopardizing the operator competitiveness in the market; }\end{array}$ \\
\cline { 2 - 3 } & $\begin{array}{l}\text { To eliminate the inequity and unfairness of charges for passenger and freight } \\
\text { trains when determining the unit costs, coefficients and weights for these two } \\
\text { markets segments; }\end{array}$ \\
& $\begin{array}{l}\text { To send clear messages to the operators as to the direction in which they should } \\
\text { act in order to reduce their costs related to charges and to be more competitive in } \\
\text { the transport market; }\end{array}$ \\
\hline
\end{tabular}

Finally, the redesigned TAC structure for the railways of Montenegro should be an additive formula with clearly defined segments for charging for capacity and for charging for wear and tear.

\section{Conclusions}

The results of the study presented in this paper suggest that track access charge development in European countries is at the beginning of the second phase of its development, in conditions when competition is still weak and markets are still dominated by incumbents. In case of Montenegrin railways, as many as 8 out of 12 challenges in access charges are still a significant problem for stakeholders in the railway sector. It seems that the models of track access charges were not adjusted to the needs of market actors, the responsible ministries and the regulatory body.

However, it is important to note the key findings of the study.

The strongest concern should be dedicated to a clear coverage of costs that determines unit prices per train $\mathrm{km}$ or gross tone $\mathrm{km}$, as well as clear relations between elements in the formula for access charge calculation. These were the two most important factors that justified the access charge model redesign in Montenegro. This pattern is likely to be repeated in other European countries in the phase of access charges model redesign, especially if they have small railways.

This problem is closely bound up with the structure of access charge modelling. For most respondents, the only solution was clear distinctions between capacity charges and wear-and-tear charges. As one interviewee put it: "infrastructure manager need to be clear about what cost they want to charge: capacity or wear and tear, or both". 
It can be noted that the issue of the inequality and unfairness of the access charge system according to market segments (passenger and freight) was also highly positioned in the interviewees' responses. It is obvious that budgeting problems for the railway sector in the Ministry of Finance (subsidy for PSO and infrastructure) continue to be broken down and settled via the access charge model, which is causing dissatisfaction among market actors. This is usually to the detriment of freight operators, such as it is in the case of Montenegro.

The case of Montenegro, which has ten years of experience with access charges, presents a sobering picture of the degree of satisfaction of all stakeholders in the railway sector. Stakeholders were divided into three groups: state administration and regulatory bodies, infrastructure manager and train operator companies. Their disagreement over the track access charge regime was minimal, even though they have different interests. All respondents clearly indicated preferences on which direction the access charges for the use of the infrastructure should go.

Generally, the Montenegro case study shows that the proposed approach can pave the way for determining the principles on which the current TAC model should be redesigned in any country. This was accomplished by survey methods and statistical analysis.

For the first time, a methodology has been proposed and it indicated how to periodically check the benefits and shortcomings of the TAC structure while taking into consideration the goals of all stakeholders. This methodology for TAC model redesign can be considered as methodological umbrella for the TAC model redesign of all countries. This methodological umbrella offers not only the procedure and survey, but also, in a broader sense, indicates how to gather a body of expert knowledge on TAC structure and pave the way toward an acceptable TAC redesign.

Author Contributions: Conceptualization, B.B.; methodology, B.B. and M.B.; software, G.S.; validation, M.B. and G.S.; formal analysis, B.B. and R.D.; investigation, B.B. and M.B.; data curation, M.B. and B.B.; writing-original draft preparation, B.B., M.B., G.S. and R.D.; writing-review and editing, M.B.; visualization, M.B.; supervision, R.D.; project administration, M.B.; funding acquisition, B.B. All authors have read and agreed to the published version of the manuscript.

Funding: This research received no external funding. This paper is result of research extension within the project Technical assistance for Capacity Support to the Transport Sector and EU Acquis Alignment in Montenegro PWA/MNE/IPA II/CAP17/SER/01-8132/1.

Institutional Review Board Statement: Not applicable.

Informed Consent Statement: Not applicable.

Data Availability Statement: The data presented in this study are available on request from the corresponding author. The data are not publicly available due to business secret.

Acknowledgments: Authors are grateful to all stakeholders in Montenegro railway sector who have taken time to give an interview and provide examples and insights that we considered useful for this research.

Conflicts of Interest: The authors declare no conflict of interest. The funders had no role in the design of the paper; in the collection, analyses, or interpretation of data; in the writing of the manuscript, or in the decision to publish the results.

\section{Appendix A}

Please give your opinion about the current TAC structure (formula) bearing in mind the interest and requirements of your company or authority. 
Table A1. Questionnaire.

\begin{tabular}{|c|c|c|c|c|}
\hline $\begin{array}{l}\text { Question } \\
\text { Number }\end{array}$ & Question Description & Agree & Neutral & Disagree \\
\hline 1 & $\begin{array}{l}\text { Cost covering based on which the unit price is } \\
\text { defined is non-transparent and unclear. }\end{array}$ & & & \\
\hline 2 & $\begin{array}{l}\text { The costs included in the current model do not } \\
\text { satisfy the requirements of Directive } 909 / 2015 \text {. }\end{array}$ & & & \\
\hline 3 & $\begin{array}{l}\text { The level of charges is such that it significantly } \\
\text { affects the operator's competitiveness on the } \\
\text { transport market. }\end{array}$ & & & \\
\hline 4 & $\begin{array}{l}\text { The budget and budgetary restrictions for the } \\
\text { infrastructure manager are unknown/uncertain } \\
\text { during the TAC model development and thus } \\
\text { negatively impact the TAC redesign and level of } \\
\text { charges. }\end{array}$ & & & \\
\hline 5 & $\begin{array}{l}\text { TAC methodology is fully complied with the EU } \\
\text { legislation requirements. }\end{array}$ & & & \\
\hline 6 & $\begin{array}{l}\text { The level of charges for passenger and freight trains } \\
\text { is unfair and the ratio is non-rational. }\end{array}$ & & & \\
\hline 7 & $\begin{array}{l}\text { There should be a clear differentiation between the } \\
\text { charging of infrastructure capacities and wear and } \\
\text { tear in the formula for calculation of charges. }\end{array}$ & & & \\
\hline 8 & $\begin{array}{l}\text { Relations between the elements in the current TAC } \\
\text { formula are obsolete and do not reflect the unit costs } \\
\text { by place of origin and cause. }\end{array}$ & & & \\
\hline 9 & $\begin{array}{l}\text { The scale of coefficient values for the network } \\
\text { segments is rational and transparently defined. }\end{array}$ & & & \\
\hline 10 & $\begin{array}{l}\text { Train weight classes and the corresponding } \\
\text { coefficient value are adequate (based on objective } \\
\text { research). }\end{array}$ & & & \\
\hline 11 & Charging for path reservation is a problem. & & & \\
\hline 12 & $\begin{array}{l}\text { The system of charges for train delays is } \\
\text { well-defined and acceptable. }\end{array}$ & & & \\
\hline
\end{tabular}

\section{References}

1. Djordjević, B.; Mane, A.S.; Krmac, E. Analysis of dependency and importance of key indicators for railway sustainability monitoring: A new integrated approach with DEA and Pearson correlation. Res. Transp. Bus. Manag. 2021, 100650. [CrossRef]

2. Casullo, L. The Efficiency Impact of Open Access Competition in Rail Markets. International Transport Forum Discussion Paper. 2016. Available online: https:/ / www.itf-oecd.org/sites/default/files/docs/dp201607.pdf (accessed on 5 November 2021).

3. Bougette, P.; Gautier, A.; Marty, F. Which access to which assets for an effective liberalization of the railway sector? Compet. Regul. Netw. Ind. 2021, 22, 87-110. [CrossRef]

4. Laroche, F.; Sys, C.; Vanelslander, T.; Van de Voorde, E. Imperfect competition in a network industry: The case of the European rail freight market. Transp. Policy 2017, 58, 53-61. [CrossRef]

5. Besanko, D.; Cui, S. Regulated versus negotiated access pricing in vertically separated railway systems. J. Regul. Econ. 2019, 55, 1-32. [CrossRef]

6. Bošković, B.; Nuhodžić, R.; Bugarinović, M. The Sustainability of Small Countries' Railway Sector Institutions in Liberalized MarketCase Study Montenegro; World Congress on Railway Research (WCRR): Milan, Italy, 2016; Available online: https:/ / www.sparkrail. org/Lists / Records / DispForm.aspx?ID=23409 (accessed on 5 November 2021).

7. Benedetto, V.; Smith, A.S.; Nash, C.A. Evaluating the roles and powers of rail regulatory bodies in Europe: A survey-based approach. Transp. Policy 2017, 59, 116-123. [CrossRef]

8. Bugarinović, M. Modeling of Access Charges for the Use of Railway Infrastructure. Ph.D. Thesis, University of Belgrade, Belgrade, Serbia, 2014. (In Serbian). 
9. Kopp, M. Track Access Charges in EU. Railway Costing and Pricing; UIC Study Track Access Charges for Freight Trains; International Union of Railways: Paris, France, 2015; Available online: https://www.unescap.org/sites/default/files/2.\%20Track\%20Access\% 20Charges\%20in\%20EU.pdf (accessed on 5 November 2021).

10. Teixeira, P.; Pita, A.L. Infracharges; UIC study on railway infrastructure charges in Europe, Final report; Railway Technical Publications: Barcelona, Spain, 2012; Available online: https:/ /www.shop-etf.com/en/infracharges-uic-study-on-railwayinfrastructure-charges-in-europe (accessed on 5 November 2021).

11. Link, H. Rail infrastructure charging and on-track competition in Germany. Int. J. Transp. Manag. 2004, 2, 17-27. [CrossRef]

12. Link, H. Unbundling, public infrastructure financing and access charge regulation in the German rail sector. J. Rail. Transp. Plan. Manag. 2012, 2, 63-71. [CrossRef]

13. Crozet, Y. European railway infrastructure: Towards a convergence of infrastructure charging? Int. J. Transp. Manag. 2004, 2, 5-15. [CrossRef]

14. Crozet, Y.; Chassagne, F. Rail access charges in France: Beyond the opposition between competition and financing. Res. Transp. Econ. 2013, 39, 247-254. [CrossRef]

15. Crozet, Y. Track Access Charges: Reconciling Conflicting Objectives Case Study_France: Logic and Limits of Full Cost Coverage; CERRE: Brussels, Belgium, 2018; pp. 1-26. Available online: https://cerre.eu/wp-content/uploads/2020/06/180509_CERRE_ TrackAccessCharges_CaseStudy_France_final.pdf (accessed on 5 November 2021).

16. Abramović, B. Infrastructure Access Charges. Road Veh. Autom. 2017, 39, 45-58. [CrossRef]

17. Ministry of Capital Investment. Railway Strategy for the Period 2017-2027; Ministry of Capital Investments: Podgorica, Montenegro, 2017. Available online: https:/ / www.gov.me/en/documents/5b241a59-db74-4bf6-a3d6-1453dda6dc03 (accessed on 5 November 2021).

18. Nash, C. Rail infrastructure charges in Europe. J. Transp. Econ. Policy. 2005, 39, 259-278. Available online: http://eprints. whiterose.ac.uk/2032/ (accessed on 5 November 2021).

19. Ciuffini, F.; Ricci, S.; Sitongi, G.R. Track access charge algorithms in EU railway: A dynamic benchmarking. In Proceedings of the 2nd International Conference on Road and Rail Infrastructure, Dubrovnik, Croatia, 7-9 May 2012; pp. 161-168. Available online: https:/ / master.grad.hr/cetra/ocs/index.php/cetra/cetra2012/paper/view/190 (accessed on 5 November 2021).

20. Rotoli, F.; Valeri, E.; Ricci, S.; Rizzetto, L.; Malavasi, G. An analysis of the railway access charges regime in the Italian context. Transp. Policy 2018, 64, 20-28. [CrossRef]

21. Bugarinovic, M.; Boskovic, B. A systems approach to access charges in unbundling railways. Eur. J. Oper. Res. 2015, 240, 848-860. [CrossRef]

22. Melander, L. Scenario development in transport studies: Methodological considerations and reflections on delphi studies. Futures 2018, 96, 68-78. [CrossRef]

23. Gnatzy, T.; Warth, J.; von der Gracht, H.; Darkow, I.-L. Validating an innovative real-time Delphi approach - A methodological comparison between real-time and conventional Delphi studies. Technol. Forecast. Soc. Chang. 2011, 78, 1681-1694. [CrossRef]

24. Cohen, L.; MAnion, L.; Morison, K. Research Methods in Education; Routledge: London, UK, 2007; Available online: https: / /gtu.ge/Agro-Lib/RESEARCH\%20METHOD\%20COHEN\%20ok.pdf (accessed on 5 November 2021).

25. Tullis, T.; Albert, B. Measuring the User Experience. Collecting, Analyzing and Presenting Usability Metrics, 2nd ed.; Elsevier Inc.: Amsterdam, The Netherlands, 2013; Available online: https://www.sciencedirect.com/book/9780124157811/measuring-theuser-experience (accessed on 5 November 2021).

26. Meyer, S. Expanded tables of critical values for the Kruskal-Wallis H statistic. In Proceedings of the Annual Meeting of the American Educational Research Association, San Francisco, CA, USA, 7-11 April 2006; Available online: https://www.jstor.org/ stable/26594373 (accessed on 5 November 2021).

27. Kruskal, W.H.; Wallis, W.A. Use of Ranks in One-Criterion Variance Analysis. J. Am. Stat. Assoc. 1952, 47, 583. [CrossRef]

28. RMMS. Seventh Monitoring Report on the Development of the Rail Market under Article 15(4) of Directive 2012/34/EU of the European Parlament and of the Council. Brussels, Belgium, 2021. Available online: https:/ / op.europa.eu/en/publication-detail/ - / publication/4403ba11-5588-11eb-b59f-01aa75ed71a1 (accessed on 5 November 2021).

29. Bugarinović, M.; Bošković, B. TAC Methodology for Montenegro. Part of the Project Technical Assistance for Capacity Support to the Transport Sector and EU Acquis Alignment in Montenegro PWA/MNE/IPA II/CAP17/SER/01-8132/1; TAC Methodology for Montenegro: Podgorica, Montenegro, 2021. 